\title{
The Insulin-Like Growth Factor System in Bone:
}

\author{
Basic and Clinical Implications
}

Masanobu Kawai, MD, PhDa and Clifford J. Rosen, MD ${ }^{b,{ }^{*}}$

aDepartment of Bone and Mineral Research, Osaka Medical Center and Research Institute for Maternal and Child Health, Izumi, Osaka, Japan 594-1101

${ }^{b}$ Center for Translational Research, Maine Medical Center Research Institute, Scarborough, ME 04074, USA

\section{Keywords}

Insulin-like growth factors; Skeletal growth; Bone homeostasis; Insulin-like growth factor binding protein

\section{INTRODUCTION}

The insulin-like growth factor (IGF) regulatory system consists of IGFs (IGF-I and IGF-II), IGF receptor, and regulatory proteins including IGF-binding proteins (IGFBP-1 to IGFBP-6) and the acid-labile subunit (ALS). ${ }^{1}$ The biological function of this system is diverse, whereby IGFs function as potent mitogens and, in some circumstances, differentiation factors. IGFs are bound in binary (to IGFBPs) or ternary complexes (IGF-ALS-IGFBP-3 or -IGFBP-5), with little free IGF-I or IGF-II in either the circulation or the extracellular fluid. IGF bioavailability is regulated by the interaction of these molecules at the receptor level; hence, changes in any component of the system can have profound effects on the biological activity of the ligands. The IGFBPs have a particularly important role in regulating IGF-I access to its receptor because their binding affinity exceeds that of the IGF receptors. What makes the IGF system unique is that the IGFBPs are regulated in a cell-specific manner at the pericellular microen-vironment, such that small changes in their concentrations could have a profound effect on mitogenic activity of IGF-I. ${ }^{2-4}$ In the skeleton, IGF-I and IGF-II are extremely abundant, and are stored in their inactive form bound to several IGFBPs within the matrix. Release of the IGFs in their active form during bone modeling and remodeling is a critical aspect of skeletal homeostasis. In addition to the ubiquitous expression of the IGFs, these growth factors circulate in high concentrations and, because of the rich blood supply of the cortical and trabecular skeleton, allow exposure of bone cells to these peptides.

The main source of circulating IGF-I in mammals is the liver, and its role as an endocrine mediator of growth hormone has been established for half a century. Although nearly $80 \%$ of the circulating IGF-I comes from hepatic sources, IGF-I synthesized from the local tissues including bone may contribute to the total circulating pool as well. The expression diversity of IGF-I and the IGFBPs in a tissue-specific manner coupled with a large circulating pool adds several levels of complexity to our understanding of the role of the IGF-I/IGFBP system. However, there is little doubt that IGF-I signaling is requisite for

(C) 2012 Elsevier Inc. All rights reserved.

*Corresponding author. ROSENC@mmc.org. 
proper skeletal accrual. This review discusses the roles of the IGF system in the regulation of skeletal homeostasis.

\section{IGF-I REGULATORY SYSTEM AND BONE}

The IGF regulatory system includes IGF-I, IGF-I receptor (IGF1R), regulatory proteins including IGFBP- 1 to -6 , and the ALS. ${ }^{5}$ All of these components except ALS are expressed in relatively high concentrations within bone. IGF-I is a single-chain poly-peptide and consists of 70 amino acid residues. The distribution of IGF-I in serum and skeletal environment is an important component of IGF-I action, and is determined by the relative saturation by IGFBPs. In a manner analogous to other tissues, this family of proteins can act as agonists for IGF-I or can block the actions of IGF-I by preventing access to the IGF1R in bone. The redundancy exerted by the IGFBPs in the IGF regulatory system provides an additional level of regulation, and can be used to deliver IGF-I in an endocrine fashion.

IGF-I exerts its action by binding to the IGF-I receptor, which induces receptor autophosphorylation in the intracellular kinase domain. On receptor activation several protein substrates, including insulin receptor substrate 1 (IRS-1) and Src homolog and collagen protein (SHC), are activated, and transduce multiple signaling pathways, including the PI3K/PDK-1/Akt pathway and Ras/Raf-1/MAPK 9mitogen-activated protein kinase) pathway. IRS-1 interacts with phosphatidylinositol-3-kinase (PI3K), and activation of PI3K catalyzes a phosphorylation of phosphatidylinositol-4,5-diphosphate (PIP2) to phosphatidylinositol-3,4,5-trisphosaphate (PIP3). The Increased PIP3 level activates phosphoinositide-dependent kinase 1 (PDK-1) and Akt. The Ras/Raf-1/MAPK pathway is activated through the SHC-Grb2-SOC complex, which is critical for cell proliferation. Activation of the PI3K/PDK-1/Akt pathway has been shown to be important in skeletal acquisition in vitro and in vivo. ${ }^{6,7}$ For example, Akt1 and Akt2 double knock-out mice show severely delayed skeletal development. ${ }^{7}$ The precise mechanisms underlying the effect of the PI3K/Akt pathway on skeleton need to be clarified; however, it is known that cell survival $^{8}$ and cell migration induced by this pathway are important. Migration of mesenchymal stem cells and/or osteoblasts is an important component in skeletal development, bone remodeling, and fracture healing. For example, during bone remodeling initial resorption by osteoclasts leads to elaboration of matrix proteins and calcium. IGF components are also released during acidification of the resorption surface, and it is thought that IGF-I may be critical for attracting osteoblast precursors to the endos-teal surfaces. Whether the IGFs may also enhance osteoblast differentiation, thereby promoting bone formation, remains to be demonstrated. Previous studies have shown that dominant-negative Akt suppressed Runx2-induced osteoblastic cell migration and PI3K inhibitor suppressed IGF-I-induced cell migration of MC3T3-E1 cells. ${ }^{9,10}$ As such, beyond its role as a mitogen, IGF-I may function as a chemotactic factor, particularly in the skeleton.

\section{ANIMAL STUDIES}

Recent advances in molecular biology and development of genetically modified mice have expanded our understanding of the role of IGF-I in the skeleton. The first evidence of the involvement of IGF-I in bone biology using a genetically engineered mouse model comes from the study in which mice lacking the IgfI gene were generated. ${ }^{11}$ More than $80 \%$ of these mice died perinatally, but survivors reached adulthood and showed postnatal growth retardation. Subsequently, IGF-I heterozygous mice on CD-1 background were analyzed and demonstrated a reduction in cortical bone mineral density associated with decreased serum IGF-I levels, suggesting that IGF-I is a determinant of bone mass in postnatal life. ${ }^{12}$ Bikle and colleagues ${ }^{13}$ also reported a unique skeletal phenotype of IGF-I null mice. These mice exhibited a $24 \%$ reduction in the size of cortical bone and shortened femur length compared 
with controls, whereas trabecular bone density and connectivity were increased. ${ }^{14}$ This mixed phenotype of these mice may be at least in part explained by their impaired osteoclastogenesis, because cocultures of osteoblasts from IGF-I null mice and osteoclast precursors from wild-type mice, as well as osteoblasts from wild-type mice and osteoclast precursors from IGF-I null mice showed reduced numbers of osteoclasts. In addition, expression of receptor activator of nuclear factor $\kappa \mathrm{B}$ ligand (RANKL) was impaired in IGF-I null osteoblasts isolated from the bone marrow, and expression of RANKL, RANK, and macrophage colony-stimulating factor in long bones were all reduced in IGF-I null mice.

IGF-I transgenic mice under the control of metallothionein promoter resulted in increased body weight and disproportionate overgrowth of some organs with elevated serum IGF-I levels, but skeletal size and morphology was normal. ${ }^{15}$ IGF1R-deficient mice showed organ hypoplasia, delayed skeletal calcification, severe growth retardation, and invariably died postnatally as a result of respiratory dysfunction. The fact that cross-breeding of IGF-I null mice and IGF1R null mice exhibit a phenotype, which is indistinguishable from the one noted in IGF1R null mice, indicates that IGF-I mediates its action exclusively through the IGF1R. ${ }^{11}$

To overcome the long-standing struggle to identify the role of locally produced IGF-I, IGF-I transgenic mice under the osteocalcin promoter were generated. ${ }^{16}$ Serum IGF-I levels and body growth were not altered in these mice, but they showed increased bone mineral density and trabecular bone volume, though cortical bone volume was not altered. The change was accompanied by increased bone formation. Of note is that osteoblast number was not altered. Thus, the anabolic effect of locally produced IGF-I by osteoblasts is exerted by enhancing osteoblast function, not by recruiting osteoblasts from osteogenic precursor cells. In line with these observations, mice lacking IGF1R in an osteoblast-specific manner were of normal body size and weight, but demonstrated reduced trabecular bone volume, connectivity, and trabecular number, as well as increased trabecular spacing. ${ }^{17}$

In addition to the locally produced IGF-I, critical roles of circulating IGF-I in skeletal homeostasis have been clarified using genetically engineered mouse models. Yaker and colleagues $^{18,19}$ generated a liver-specific IGF-I deficient mouse (LID mouse) under the control of albumin promoter and clarified the role of IGF-I produced by liver on the skeleton. LID mice showed relatively normal development despite the reduction in serum IGF-I levels by $75 \%$; surprisingly, femur length and body weight decreased by only $6 \%$, but cortical bone volume was reduced by $26 \%$ and trabecular bone volume was preserved. Periosteal circumference and cross-sectional area were also markedly reduced. ${ }^{20}$ To gain more insights regarding the role of circulating IGF-I in bone mass, the ALS was deleted in another mouse model (ALSKO mouse). As expected, serum IGF-I levels in ALSKO mice were reduced by $65 \%$ and cortical bone volume was reduced. Double knock-out liver IGF-I and ALS mice demonstrated a marked decrease in serum IGF-I of $85 \%$ to $90 \%$, despite normal expression of skeletal IGF-I. The skeletal phenotype of these mice included reduced cortical bone volume and significant growth retardation with disordered growth plates. Taken together, these data suggest that circulating IGF-I is important for longitudinal growth, and the modeling of bone, particularly periosteal expansion. To better understand the role of circulating IGF-I, 2 independent groups generated transgenic mice expressing IGF-I in liver on an IGF-I null background. Stratikopoulos and colleagues ${ }^{21}$ produced a mouse model in which IGF-I cDNA is regulated under a native promoter/enhancer of IGF-I gene only in liver on an Igfl null background, and revealed that endocrine IGF-I contributed approximately $30 \%$ of the adult mouse body size. Similarly, Elis and colleagues ${ }^{22}$ generated Igfltransgenic mice under transthyretin promoter on an Igfl null background (KO-HIT [hepatic IGF-I transgenic mice]). KO-HIT mice showed an approximately 3 -fold increase in serum IGF-I levels. The body weight of KO-HIT mice was comparable with that of controls 
up to 16 weeks, but these mice showed shorter femorae at 4 weeks of age and exhibited catch-up growth by 8 weeks of age. These data suggested that locally expressed IGF-I is important in the regulation of body length during first the 4 weeks of life, but circulating IGF-I can compensate for the loss of local IGF-I after 4 weeks of age. In respect of the skeletal phenotype, KO-HIT mice had shorter femorae and smaller bone size at 4 weeks of age, but then showed a marked increase in these parameters. Thus, circulating IGF-I can compensate for the loss of locally produced IGF-I in a developmentally stage-specific manner.

Analyses of the role of signaling molecules that lie downstream of IGF1R activation have provided another level of evidence to support the importance of IGF-I in skeletal homeostasis. For example, insulin receptor substrates (IRSs) are the best defined IGF1R substrates and consist of 4 members. Several studies have demonstrated that IRS- 1 is involved in bone acquisition. ${ }^{23}$ IRS-1 null mice show severe osteopenia with low bone turnover. IRS-1-deficient osteoblasts from these mice revealed that IRS-1 deficiency reduces cell proliferation and differentiation in response to IGF-I and cannot support osteoclastogenesis, leading to low-turnover osteopenia. PTEN (phosphatase and tensin homolog deleted on chromosome 10) is a lipid phosphatase and opposes IGF-I signaling by dephosphorylating PIP3 to PIP2. Mice deficient in PTEN only in osteoblasts were created by use of the human osteocalcin promoter. These mice showed progressively increasing bone mineral density throughout life. The PI3K pathway was activated constitutively in these mice, and the osteoblasts were protected from apoptosis. ${ }^{24}$ These findings indicate the importance of PTEN and the PI3K system in bone acquisition.

\section{ROLE OF THE IGFBP s IN THE SKELETON}

IGF-I bioactivity is modulated by the IGFBPs (IGFBP-1 to -6), and their role in skeletal acquisition has been analyzed using genetically altered mice. The function of IGFBPs with respect to IGF-I signaling depends on the relative molar ratio between IGFBPs and IGF-I, but IGFBPs are primarily considered to work as inhibitors for IGF-I, as is true for IGFBP-2, which has been shown to block IGF-I binding to its receptor. Hence, IGFBP-2 has been regarded as a negative regulator for IGF-I-induced bone acquisition. For example, in vitro analysis revealed that IGFBP-2 inhibited IGF-I-stimulated bone cell proliferation, collagen synthesis, and bone formation. In vivo, overexpression of $I g f b p 2$ has been demonstrated to reduce bone mass and inhibit growth hormone $(\mathrm{GH})$-stimulated linear growth in $\mathrm{GH}$ transgenic mice, possibly by antagonizing the GH/IGF-I axis. ${ }^{25}$ Of note, the effect of IGFBP-2 on bone accrual is also evidenced by human studies in which serum IGFBP-2 levels were inversely associated with bone mass. ${ }^{26-28}$ Amin and colleagues ${ }^{26}$ reported that IGFBP-2 levels increased with age and that serum IGFBP-2 levels showed negative association with bone mineral density in both men and women. van den Beld and colleagues $^{27}$ showed that higher serum IGFBP-2 levels were associated with a higher degree of disability and a lower physical performance, muscle strength, and bone mineral density of proximal femur. However, growing evidence demonstrates that the effect of IGFBP-2 on bone mass is context specific, such that IGFBP-2 has an anabolic effect on skeleton. For example, Khosla and colleagues ${ }^{29,30}$ reported that IGFBP-2 stimulated bone formation in association with IGF-II in patients with hepatitis C-associated osteosclerosis. Igfbp $2^{-/-}$mice have been shown to exhibit a gender-specific and compartment-specific skeletal phenotype; $\operatorname{Igfb} \mathrm{f}^{-/-}$females had increased cortical thickness with a greater periosteal circumference, whereas $\operatorname{Igfbp} 2^{-/-}$males had reduced cortical bone size. Trabecular bone volume was reduced by $20 \%$ in $I g f b p 2^{-/-}$males whereas trabecular bone was not affected in female

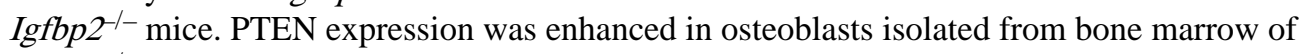
Igfbp $2^{-/-}$mice compared with controls. Because PTEN regulates IGF-I signaling in a negative direction, IGF-I signaling may be impaired in $\operatorname{Igfbp} 2^{-1-}$ mice. Recently, the authors 
have identified a unique heparin-binding domain (HBD) in IGFBP-2 which, at least in part, mediates the anabolic effect of IGFBP-2. Administration of the HBD of IGFBP-2 in $I g f b p 2^{-/-}$mice partially rescued the osteopenic phenotype of these mice. The molecular mechanisms of the HBD of IGFBP-2 needs to be determined, but the HBD is implicated in downregulating PTEN expression and activates IGF-I signaling pathway in osteoblasts, indicating that the effect of the HBD on bone acquisition is in part mediated by the reduction of PTEN expression in osteoblastic cells.

IGFBP-3 is the predominant IGFBP, and forms a tertiary complex with IGF-I and ALS. Similar to other IGFBPs, IGFBP-3 can have an antagonistic effect on IGF-I signaling. Skeletal phenotypes of Igfbp 3 transgenic mice demonstrated decreased cortical and trabecular bone mineral density. ${ }^{31}$ However, there is some evidence to suggest that IGFBP-3 can have a positive effect on bone formation in some situations. For example, IGFBP-3 has been shown to bind to the type I collagen molecule, thereby playing a role in storing IGFs within the skeletal matrix.

IGFBP-4 is one of the most abundant IGFBPs synthesized by bone cells, and has been shown to be inhibitory for IGF-I signaling in vitro. Targeted overexpression of Igfbp4 in bone using the human osteocalcin promoter results in postnatal growth retardation, altered bone turnover, and low bone mass. ${ }^{32} \mathrm{Igfbp4^{-- }}$ mice also have modest growth retardation at birth and reduced bone mineral density, suggesting that it may play an important role as a storage protein in bone. ${ }^{33}$ IGFBP-5 can bind extracellular matrices through a conserved HBD. Its role in bone formation has been considered both within the realm of its role as a storage protein and as a potential agonist for IGF-I, although a receptor for IGFBP-5 has not been identified. Transgenic Igfbp 5 mice under the control of osteocalcin promoter showed decreased bone volume with low bone formation. ${ }^{34}$ Taken together, these lines of evidence demonstrate that physiologic levels of IGFBPs have an anabolic effect on skeleton, at least in part through targeting IGF-I to the skeletal microenvironment.

\section{ROLE OF IGF-I IN THE SKELETON}

\section{Human Studies}

It is well established that serum IGF-I levels are positively associated with bone mass. ${ }^{5}$ For example, serum IGF-I levels peak at puberty when the bone acquisition is maximized, and decline with aging accompanied by the aging-related bone loss. This positive correlation is also relevant in neonates. ${ }^{35}$ Clinical studies of patients with disturbances in the GH-IGF-I axis have provided significant evidence of the importance of IGF-I in maintaining the bone mass. Children and adults with GH deficiency, whose serum levels of IGF-I are low, have low areal bone mineral density (aBMD), and bone mass recovers after GH replacement therapy associated with significant increments in serum IGF-I. ${ }^{36-38}$ In patients with a GHreceptor deficiency (primary IGF-I deficiency, Laron syndrome), bone mass has long been suggested to be low, but this tenet might not be true because there is increasing evidence that when volumetric bone mineral density is measured there are no changes in bone mass, probably due to the small bone area and short stature of these patients. ${ }^{39,40} \mathrm{~A}$ similar trend is also observed in patients with severe IGF-I deficiency caused by homozygous mutation in the IgfI gene ${ }^{41-44}$ and patients with mutation in the IgfI receptor gene. ${ }^{45-47}$ These findings are informative, but conclusions may be tenuous, owing to several covariates and small subject numbers.

Cohort studies in adult populations have also provided clinical evidence of the positive relationship between IGF-I and bone mass, but this might be context specific because there is evidence that serum IGF-I levels are not associated with bone mass in men. ${ }^{48}$ Langlois and colleagues ${ }^{48}$ investigated the relationship between serum IGF-I and bone mineral 
density from the Framingham Heart Study, and reported that IGF-I levels were positively correlated with aBMD at all sites of the hip, radius, and lumbar spine in women, whereas IGF-I was not significantly associated with bone mineral density in men. Bauer and colleagues ${ }^{49}$ examined the relationship of IGF-I and IGFBP-3 to hip fractures in 9704 women from the Study of Osteoporotic Fractures. In that study, women in the lowest quartile for serum IGF-I had a $60 \%$ greater risk of hip or spine fracture, whereas IGFBP-3 did not show any correlation. Garnero and colleagues ${ }^{50}$ also demonstrated that serum IGF-I levels in older individuals were related to hip fracture risk. These studies suggest there is a positive correlation between serum IGF-I concentrations and bone mineral density.

However, it is unclear how IGF-I is involved in the pathogenesis of osteoporosis, because serum IGF-I levels are strongly influenced by catabolic states, undernutrition, surgery, and advanced age, all of which are risk factors for fractures.

Linkage analysis in humans has also implicated the possible role of Igfl gene as contributing to the bone mass. ${ }^{51,52}$ For example, CA-repeat promoter polymorphisms in the Igf1 gene have been shown to be associated with bone mass. ${ }^{53-55}$ However, the importance of CA-repeat polymorphisms needs to be clarified because some studies could not find any association between bone mineral density and this polymorphism in premenopausal Caucasian and African American women ${ }^{56}$ and in premenopausal Chinese women. ${ }^{57}$ These data suggest that IGF-I polymorphisms may be associated with bone mass, but there is significant genetic heterogeneity.

\section{Clinical Studies with IGFS and IGFBPs}

Recombinant human IGF-I (rhIGF-I) has been used with success to treat GH resistance and IGF-I deficiency syndromes in children, although clinical use is not widespread, in part because of metabolic adverse effects including hypoglycemia and hypophosphatemia. ${ }^{58}$ On the other hand, administration of rhIGF-I to enhance bone formation and improve bone mass has been met with major limitations. The first long-term study was initially done nearly 20 years ago ${ }^{59}$ However, clinical trial studies of rhIGF-I in osteoporotic patients have been limited. In a trial of 16 healthy elderly women $(71.9 \pm 31.3$ years of age), a high dose of rhIGF-I $(60 \mu \mathrm{g} / \mathrm{kg} / \mathrm{d})$ or a low dose of rhIGF-I $(15 \mu \mathrm{g} / \mathrm{kg} / \mathrm{d})$ was administered for 28 days, and bone resorption and formation markers were analyzed. ${ }^{60}$ The high-dose rhIGF-I increased both bone resorption and bone formation markers, but low-dose rhIGF-I did not affect bone resorption markers. Subsequent work proved that IGF-I was a potent stimulus for osteoclast differentiation, ${ }^{61}$ suggesting that IGF-I was a "coupler" of bone remodeling; that is, a stimulus for both resorption and formation. In addition, there were concerns from that first study about clinically significant hypoglycemia. Boonen and colleagues ${ }^{62}$ reported that the administration of a complex, IGF-I coupled to IGFBP-3, resulted in reduced bone loss from the femur in elderly patients with hip fractures, as well as some improvement in functional outcomes. However, no further studies were subsequently conducted using this complex in skeletal disorders (Fig. 1).

\section{Summary}

There is no doubt that the IGF regulatory system (both locally and systemically) is critical for skeletal growth and maintenance. This fact is reinforced by studies showing that rhIGF-I has been used with success in a limited number of growth disorders. With respect to adults, serum levels of IGF-I have been strongly associated with osteoporosis, as have several IGFBPs. However, trials using recombinant IGF peptides or complexes to treat age-related bone disease have been limited by lack of strong anabolic activity, and significant off-target actions such as hypoglycemia and the potential for malignant transformation.

Notwithstanding, ongoing animal studies using genetic models have provided fresh insight into the role of these growth factors in skeletal homeostasis. 


\section{References}

1. Rosen CJ, Donahue LR, Hunter SJ. Insulin-like growth factors and bone: the osteoporosis connection. Proc Soc Exp Biol Med. 1994; 206:83-102. [PubMed: 8208742]

2. Hwa V, Oh Y, Rosenfeld RG. The insulin-like growth factor-binding protein (IGFBP) superfamily. Endocr Rev. 1999; 20:761-87. [PubMed: 10605625]

3. Jones JI, Clemmons DR. Insulin-like growth factors and their binding proteins: biological actions. Endocr Rev. 1995; 16:3-34. [PubMed: 7758431]

4. Firth SM, Baxter RC. Cellular actions of the insulin-like growth factor binding proteins. Endocr Rev. 2002; 23:824-54. [PubMed: 12466191]

5. Niu T, Rosen CJ. The insulin-like growth factor-I gene and osteoporosis: a critical appraisal. Gene. 2005; 361:38-56. [PubMed: 16183214]

6. Ghosh-Choudhury N, Abboud SL, Nishimura R, et al. Requirement of BMP-2-induced phosphatidylinositol 3-kinase and Akt serine/threonine kinase in osteoblast differentiation and Smad-dependent BMP-2 gene transcription. J Biol Chem. 2002; 277:33361-8. [PubMed: 12084724]

7. Peng XD, Xu PZ, Chen ML, et al. Dwarfism, impaired skin development, skeletal muscle atrophy, delayed bone development, and impeded adipogenesis in mice lacking Akt1 and Akt2. Genes Dev. 2003; 17:1352-65. [PubMed: 12782654]

8. Grey A, Chen Q, Xu X, et al. Parallel phosphatidylinositol-3 kinase and p42/44 mitogen-activated protein kinase signaling pathways subserve the mitogenic and antiapoptotic actions of insulin-like growth factor I in osteoblastic cells. Endocrinology. 2003; 144:4886-93. [PubMed: 12960100]

9. Nakasaki M, Yoshioka K, Miyamoto Y, et al. IGF-I secreted by osteoblasts acts as a potent chemotactic factor for osteoblasts. Bone. 2008; 43:869-79. [PubMed: 18718566]

10. Fujita T, Azuma Y, Fukuyama R, et al. Runx2 induces osteoblast and chondrocyte differentiation and enhances their migration by coupling with PI3K-Akt signaling. J Cell Biol. 2004; 166:85-95. [PubMed: 15226309]

11. Liu JP, Baker J, Perkins AS, et al. Mice carrying null mutations of the genes encoding insulin-like growth factor I (Igf-1) and type 1 IGF receptor (Igf1r). Cell. 1993; 75:59-72. [PubMed: 8402901]

12. He J, Rosen CJ, Adams DJ, et al. Postnatal growth and bone mass in mice with IGF-I haploinsufficiency. Bone. 2006; 38:826-35. [PubMed: 16427371]

13. Bikle D, Majumdar S, Laib A, et al. The skeletal structure of insulin-like growth factor I-deficient mice. J Bone Miner Res. 2001; 16:2320-9. [PubMed: 11760848]

14. Wang Y, Nishida S, Elalieh HZ, et al. Role of IGF-I signaling in regulating osteoclastogenesis. J Bone Miner Res. 2006; 21:1350-8. [PubMed: 16939393]

15. Mathews LS, Hammer RE, Behringer RR, et al. Growth enhancement of transgenic mice expressing human insulin-like growth factor I. Endocrinology. 1988; 123:2827-33. [PubMed: 3197646]

16. Zhao G, Monier-Faugere MC, Langub MC, et al. Targeted overexpression of insulin-like growth factor I to osteoblasts of transgenic mice: increased trabecular bone volume without increased osteoblast proliferation. Endocrinology. 2000; 141:2674-82. [PubMed: 10875273]

17. Zhang M, Xuan S, Bouxsein ML, et al. Osteoblast-specific knockout of the insulin-like growth factor (IGF) receptor gene reveals an essential role of IGF signaling in bone matrix mineralization. J Biol Chem. 2002; 277:44005-12. [PubMed: 12215457]

18. Yakar S, Liu JL, Stannard B, et al. Normal growth and development in the absence of hepatic insulin-like growth factor I. Proc Natl Acad Sci U S A. 1999; 96:7324-9. [PubMed: 10377413]

19. Yakar S, Rosen CJ, Beamer WG, et al. Circulating levels of IGF-1 directly regulate bone growth and density. J Clin Invest. 2002; 110:771-81. [PubMed: 12235108]

20. Bouxsein ML, Rosen CJ, Turner CH, et al. Generation of a new congenic mouse strain to test the relationships among serum insulin-like growth factor I, bone mineral density, and skeletal morphology in vivo. J Bone Miner Res. 2002; 17:570-9. [PubMed: 11918215]

21. Stratikopoulos E, Szabolcs M, Dragatsis I, et al. The hormonal action of IGF1 in postnatal mouse growth. Proc Natl Acad Sci U S A. 2008; 105:19378-83. [PubMed: 19033454] 
22. Elis S, Courtland HW, Wu Y, et al. Elevated serum levels of IGF-1 are sufficient to establish normal body size and skeletal properties, even in the absence of tissue IGF-1. J Bone Miner Res. 2010; 25(6):1257-66. [PubMed: 20200935]

23. Ogata N, Chikazu D, Kubota N, et al. Insulin receptor substrate-1 in osteoblast is indispensable for maintaining bone turnover. J Clin Invest. 2000; 105:935-43. [PubMed: 10749573]

24. Liu X, Bruxvoort KJ, Zylstra CR, et al. Lifelong accumulation of bone in mice lacking Pten in osteoblasts. Proc Natl Acad Sci U S A. 2007; 104:2259-64. [PubMed: 17287359]

25. Hoeflich A, Nedbal S, Blum WF, et al. Growth inhibition in giant growth hormone transgenic mice by overexpression of insulin-like growth factor-binding protein-2. Endocrinology. 2001; 142:1889-98. [PubMed: 11316754]

26. Amin S, Riggs BL, Atkinson EJ, et al. A potentially deleterious role of IGFBP-2 on bone density in aging men and women. J Bone Miner Res. 2004; 19:1075-83. [PubMed: 15176989]

27. van den Beld AW, Blum WF, Pols HA, et al. Serum insulin-like growth factor binding protein-2 levels as an indicator of functional ability in elderly men. Eur J Endocrinol. 2003; 148:627-34. [PubMed: 12773134]

28. Nakaoka D, Sugimoto T, Kaji H, et al. Determinants of bone mineral density and spinal fracture risk in postmenopausal Japanese women. Osteoporos Int. 2001; 12:548-54. [PubMed: 11527051]

29. Conover CA, Johnstone EW, Turner RT, et al. Subcutaneous administration of insulin-like growth factor (IGF)-II/IGF binding protein-2 complex stimulates bone formation and prevents loss of bone mineral density in a rat model of disuse osteoporosis. Growth Horm IGF Res. 2002; 12:17883. [PubMed: 12162999]

30. Khosla S, Hassoun AA, Baker BK, et al. Insulin-like growth factor system abnormalities in hepatitis C-associated osteosclerosis. Potential insights into increasing bone mass in adults. J Clin Invest. 1998; 101:2165-73. [PubMed: 9593772]

31. Silha JV, Mishra S, Rosen CJ, et al. Perturbations in bone formation and resorption in insulin-like growth factor binding protein-3 transgenic mice. J Bone Miner Res. 2003; 18:1834-41. [PubMed: 14584894]

32. Zhang M, Faugere MC, Malluche H, et al. Paracrine overexpression of IGFBP-4 in osteoblasts of transgenic mice decreases bone turnover and causes global growth retardation. J Bone Miner Res. 2003; 18:836-43. [PubMed: 12733722]

33. Ning Y, Schuller AG, Conover CA, et al. Insulin-like growth factor (IGF) binding protein-4 is both a positive and negative regulator of IGF activity in vivo. Mol Endocrinol. 2008; 22:1213-25. [PubMed: 18258685]

34. Devlin RD, Du Z, Buccilli V, et al. Transgenic mice overexpressing insulin-like growth factor binding protein-5 display transiently decreased osteoblastic function and osteopenia. Endocrinology. 2002; 143:3955-62. [PubMed: 12239107]

35. Javaid MK, Godfrey KM, Taylor P, et al. Umbilical venous IGF-1 concentration, neonatal bone mass, and body composition. J Bone Miner Res. 2004; 19:56-63. [PubMed: 14753737]

36. Holmes SJ, Economou G, Whitehouse RW, et al. Reduced bone mineral density in patients with adult onset growth hormone deficiency. J Clin Endocrinol Metab. 1994; 78:669-74. [PubMed: 8126140]

37. Saggese G, Baroncelli GI, Bertelloni S, et al. Effects of long-term treatment with growth hormone on bone and mineral metabolism in children with growth hormone deficiency. J Pediatr. 1993; 122:37-45. [PubMed: 8419613]

38. Rosen T, Hansson T, Granhed H, et al. Reduced bone mineral content in adult patients with growth hormone deficiency. Acta Endocrinol (Copenh). 1993; 129:201-6. [PubMed: 8212984]

39. Bachrach LK, Marcus R, Ott SM, et al. Bone mineral, histomorphometry, and body composition in adults with growth hormone receptor deficiency. J Bone Miner Res. 1998; 13:415-21. [PubMed: 9525342]

40. Benbassat CA, Eshed V, Kamjin M, et al. Are adult patients with Laron syndrome osteopenic? A comparison between dual-energy X-ray absorptiometry and volumetric bone densities. J Clin Endocrinol Metab. 2003; 88:4586-9. [PubMed: 14557426] 
41. Woods KA, Camacho-Hubner C, Bergman RN, et al. Effects of insulin-like growth factor I (IGF-I) therapy on body composition and insulin resistance in IGF-I gene deletion. J Clin Endocrinol Metab. 2000; 85:1407-11. [PubMed: 10770174]

42. Woods KA, Camacho-Hubner C, Savage MO, et al. Intrauterine growth retardation and postnatal growth failure associated with deletion of the insulin-like growth factor I gene. N Engl J Med. 1996; 335:1363-7. [PubMed: 8857020]

43. Walenkamp MJ, Karperien M, Pereira AM, et al. Homozygous and heterozygous expression of a novel insulin-like growth factor-I mutation. J Clin Endocrinol Metab. 2005; 90:2855-64. [PubMed: 15769976]

44. Bonapace G, Concolino D, Formicola S, et al. A novel mutation in a patient with insulin-like growth factor 1 (IGF1) deficiency. J Med Genet. 2003; 40:913-7. [PubMed: 14684690]

45. Raile K, Klammt J, Schneider A, et al. Clinical and functional characteristics of the human Arg59Ter insulin-like growth factor I receptor (IGF1R) mutation: implications for a gene dosage effect of the human IGF1R. J Clin Endocrinol Metab. 2006; 91:2264-71. [PubMed: 16569742]

46. Kawashima Y, Kanzaki S, Yang F, et al. Mutation at cleavage site of insulin-like growth factor receptor in a short-stature child born with intrauterine growth retardation. J Clin Endocrinol Metab. 2005; 90:4679-87. [PubMed: 15928254]

47. Abuzzahab MJ, Schneider A, Goddard A, et al. IGF-I receptor mutations resulting in intrauterine and postnatal growth retardation. N Engl J Med. 2003; 349:2211-22. [PubMed: 14657428]

48. Langlois JA, Rosen CJ, Visser M, et al. Association between insulin-like growth factor I and bone mineral density in older women and men: the Framingham Heart Study. J Clin Endocrinol Metab. 1998; 83:4257-62. [PubMed: 9851760]

49. Bauer DC, Rosen C, Cauley J, et al. the SOF Research Group. Low serum IGF-1 but not IGFBP-3 predicts hip and spine fracture: the study of osteoporotic fracture. Bone. 1998; 23(5 Suppl 1):S561.

50. Garnero P, Sornay-Rendu E, Delmas PD. Low serum IGF-1 and occurrence of osteoporotic fractures in postmenopausal women. Lancet. 2000; 355:898-9. [PubMed: 10752709]

51. Deng HW, Xu FH, Huang QY, et al. A whole-genome linkage scan suggests several genomic regions potentially containing quantitative trait Loci for osteoporosis. J Clin Endocrinol Metab. 2002; 87:5151-9. [PubMed: 12414886]

52. Karasik D, Myers RH, Cupples LA, et al. Genome screen for quantitative trait loci contributing to normal variation in bone mineral density: the Framingham Study. J Bone Miner Res. 2002; 17:1718-27. [PubMed: 12211443]

53. Kim JG, Roh KR, Lee JY. The relationship among serum insulin-like growth factor-I, insulin-like growth factor-I gene polymorphism, and bone mineral density in postmenopausal women in Korea. Am J Obstet Gynecol. 2002; 186:345-50. [PubMed: 11904589]

54. Rivadeneira F, Houwing-Duistermaat JJ, Vaessen N, et al. Association between an insulin-like growth factor I gene promoter polymorphism and bone mineral density in the elderly: the Rotterdam Study. J Clin Endocrinol Metab. 2003; 88:3878-84. [PubMed: 12915683]

55. Rivadeneira F, Houwing-Duistermaat JJ, Beck TJ, et al. The influence of an insulin-like growth factor I gene promoter polymorphism on hip bone geometry and the risk of nonvertebral fracture in the elderly: the Rotterdam Study. J Bone Miner Res. 2004; 19:1280-90. [PubMed: 15231015]

56. Takacs I, Koller DL, Peacock M, et al. Sibling pair linkage and association studies between bone mineral density and the insulin-like growth factor I gene locus. J Clin Endocrinol Metab. 1999; 84:4467-71. [PubMed: 10599704]

57. Jiang DK, Shen H, Li MX, et al. No major effect of the insulin-like growth factor I gene on bone mineral density in premenopausal Chinese women. Bone. 2005; 36:694-9. [PubMed: 15780973]

58. Laron Z. Insulin-like growth factor-I treatment of children with Laron syndrome (primary growth hormone insensitivity). Pediatr Endocrinol Rev. 2008; 5:766-71. [PubMed: 18367997]

59. Ebeling PR, Jones JD, O'Fallon WM, et al. Short-term effects of recombinant human insulin-like growth factor I on bone turnover in normal women. J Clin Endocrinol Metab. 1993; 77:1384-7. [PubMed: 8077337]

60. Ghiron LJ, Thompson JL, Holloway L, et al. Effects of recombinant insulin-like growth factor-I and growth hormone on bone turnover in elderly women. J Bone Miner Res. 1995; 10:1844-52. [PubMed: 8619364] 
61. Rubin J, Ackert-Bicknell CL, Zhu L, et al. IGF-I regulates osteoprotegerin (OPG) and receptor activator of nuclear factor-kappaB ligand in vitro and OPG in vivo. J Clin Endocrinol Metab. 2002; 87:4273-9. [PubMed: 12213884]

62. Boonen S, Rosen C, Bouillon R, et al. Musculoskeletal effects of the recombinant human IGF-I/ IGF binding protein-3 complex in osteoporotic patients with proximal femoral fracture: a doubleblind, placebo-controlled pilot study. J Clin Endocrinol Metab. 2002; 87:1593-9. [PubMed: 11932288] 


\section{KEY POINTS}

- The insulin-like growth factor (IGF) regulatory system is critical for skeletal growth and maintenance.

- An integrated interplay of circulating and local IGF-I determines the intricate balance of skeletal homeostasis.

- IGF binding protein regulates skeletal homeostasis in part through the modulation of IGF accessibility to the receptor and its turnover.

- IGF binding protein may confer a novel regulation through its unique domains independent of IGF binding. 


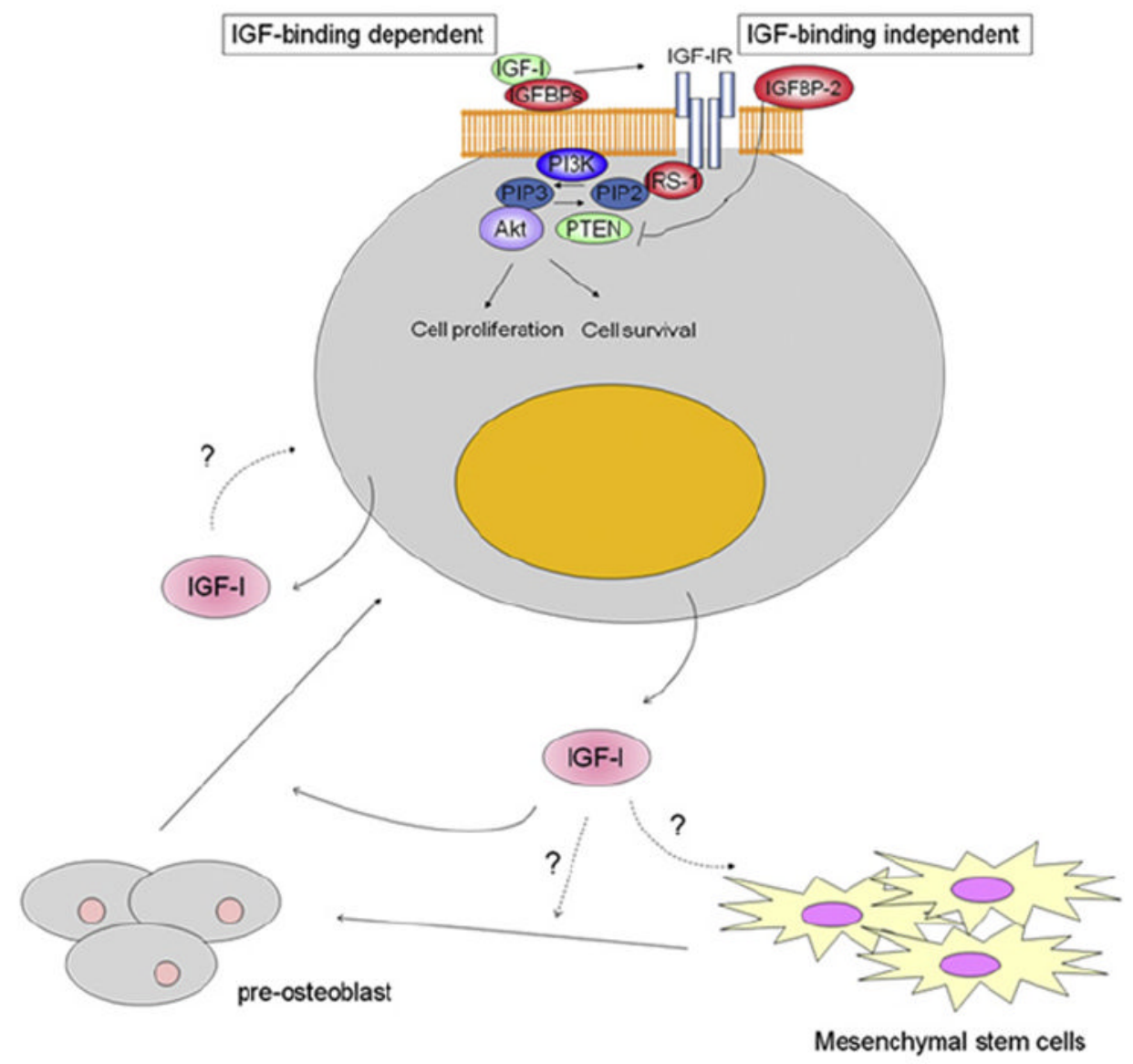

Fig. 1.

The role of insulin-like growth factor (IGF)-I and IGF-binding proteins (IGFBPs) in osteoblast differentiation. IGFBPs regulate the accessibility of IGF-I to its receptor through a manner dependent on IGF-I binding. In addition, IGFBPs can exert the unique function in a manner independent of IGF-I binding. For example, IGFBP-2 suppresses PTEN expression in osteoblastic cells through its unique heparin-binding domain, resulting in enhanced IGF-I/ Akt signaling. IGF-I produced from osteoblasts plays a critical role in osteoblast maturation and migration, but its role in the proliferation and/or differentiation of mesenchymal stem cells remains to be elucidated. IR, insulin receptor; IRS-1, insulin receptor substrate 1; PI3K, phosphatidylinositol-3-kinase; PIP2, phosphatidylinositol-4,5diphosphate; PIP3, phosphati-dylinositol-3,4,5-trisphosphate; PTEN, phosphatase and tensin homolog. 